\begin{tabular}{lll}
\hline INTERNATIONAL & \multicolumn{2}{l}{ International Journal of Health Services Research and Policy } \\
ENGINEERING, & $201 \mathrm{x}-$ Volume $: 2$ Issue $: 2$ \\
SCIENCE AND & Page : $51-57$ & (http://dergipark.gov.tr/ijhsrp) \\
INESEG & EDUCATION & doi: $10.23884 /$ ijhsrp.2017.2.2.03 \\
& GROUP (PUBLISHER) & ISSN: $2548-0359$
\end{tabular}

Received: November 1, 2017

Accepted:November 27, 2017

\title{
INVESTIGATION OF THE EFFECT OF EXERCISE ON IRISIN HORMONE IN EXPERIMENTALLY INDUCED DIABETIC RATS
}

\author{
Hazal Kucukkaraca ${ }^{* 1}$, Mehtap Unlu Sogut ${ }^{1}$ \\ ${ }^{1}$ Ondokuz Mayis University, Faculty of Health Science, Department of Nutrition and Dietetics, \\ Kurupelit Campus, Samsun/ Turkey \\ *Hazal Kucukkaraca; hazal.kucukkaraca@ omu.edu.tr
}

\begin{abstract}
Investigating the possible effects of the irisin hormone, which has been discovered in recent years, on energy expenditure and glucose metabolism has been found to have positive effects on endstage diseases. The irisin secreted by the skeletal muscle in mice and humans; is a hormone thought to improve energy consumption and improve systemic metabolism by making white fat tissue turn into brown fat tissue. Thanks to the knowledge that the structure of the irisin hormone is 100\% similar in rats and humans, researches on experimental animals may be helpful for human studies. It has been suggested that irisin, which has been studied in particular for its positive effects on obesity and diabetes, may be a promising alternative treatment for metabolic diseases. In our study that we have planned, we aimed to determine the changes that exercise will bring about at the level of irisin hormone in diabetic animal models that will be created experimentally and to evaluate the effects of these changes on diabetes, insulin resistance, lipid profile, obesity and inflammation from Metabolic Syndrome components. For this purpose, we have 3 groups; control group, diabetic and diabetic exercise group. The effects of exercise on the level of irisin hormone were investigated in the obtained serum samples. In order to observe the obesity process, the rats in each group were weighed weekly and their body weights were measured. When the weights of the groups at the beginning and 4 weeks were observed, a mean increase of $35.8 \mathrm{~g}(\mathrm{p}<0.05)$ was observed in the control group, $30 \mathrm{~g}(\mathrm{p}<0.05)$ in the diabetic group and $59 \mathrm{~g}$ in the diabetic exercise group ( $p>0.05)$. The mean fasting blood glucose value of the diabetic group was $477.17 \pm 87.98 \mathrm{mg} / \mathrm{dl}$ and the diabetic exercise group had a mean of $485 \pm 86.03$ $\mathrm{mg} / \mathrm{dl}$. When the irisin levels were examined, it was seen that there was a difference between the groups ( $p>0.05$ ). In the control group, average irisin level was $255.73 \pm 374.81 \mathrm{ng} / \mathrm{ml}$, in the diabetic group was $98.09 \pm 51.25 \mathrm{ng} / \mathrm{ml}$ and in the diabetic exercise group was of $66.43 \pm 25.01 \mathrm{ng} / \mathrm{ml}$. As a result, injectable irisin forms are produced because of irisin hormone is an important alternative in the treatment of obesity and diabetes as well as other metabolic diseases; it can be thought that the frequency can be used to control diabetes and obesity which are increasing day by day.
\end{abstract}

Keywords: irisin, diabetes, exercise, obesity. 


\section{Introduction}

Adipose tissue is an fat tissue composed of lipid-containing cells called adipocytes [1]. Adipocytes are made by lipoblasts that differentiate from mesenchymal cells. Lipoblasts are transformed into two different fatty tissues with different functions and morphology in mammals as white fat tissue (WFT) and brown fat tissue (BFT). Brown fat tissue is a fatty tissue that is specialized in heat generation (thermogenesis) [2]. There is an amount of BFT in the neonatal period, and in adulthood it is quite low $[2,3,4]$. The functional capacity of WFT is broader and more extensive [2,5]. WFT can represent the largest endocrine tissue of humans. Some of the WFT-secreted adipocytokines; leptin, ghrelin, adiponectin, glucocorticoids, plasminogen activator inhibitor (PAI-1), TNF- $\alpha$, IL-6, angiotensin, visfatin, resistin, irisin [2].

Irisin are discovered in 2012 by Boström et al. [6], is defined as a hormone secreted by the skeletal muscle linked to the exercise in mice and humans. It is thought that it increases energy consumption and develop systemic metabolism by converting white fat tissue to brown fat tissue to $[6,7,8]$. Because of these effects, it has gained tremendous popularity as a working topic in many laboratories [9]. Irisin, is a glycoprotein-structured hormone of $12 \mathrm{kDa}$ and composed of 112 amino acids; is a proteolytic product of the fibronectin type III domain 5 (FNDC5) molecule [6,10]. FNDC5, secreted from muscle tissue, is cleaved from the C-terminus and released into the environment. This part which is separated is irisin [11]. As a result of the researches it has been synthesized and released in many tissues and it is stated that the main source is skeletal muscle and fat tissue [8]. While the structure of the irisin hormone is $100 \%$ similar in humans and mice, the similarity rate of insulin is $85 \%$, glucagon $90 \%$, leptin $83 \%$ [6].

After exercise, increased FNDC5 mRNA has been reported in the skeleton of mice and humans in studies. Although, it is widely known that exercise does not reduce food intake but allows the burning of fat and calories, the molecular mechanism of this phenomenon has not been elucidated until the discovery of irisin [8]. There are studies that suggest that the release of irisin from the skeletal muscle after exercise is promoted, as well as studies that have no meaningful relationship.

Irisin is thought to have many mechanisms of action in the body. Isolation of irisin has been a guide in explaining the metabolic events and especially the fatty tissue metabolism [7,8]. It is thought to be able to prevent the onset of obesity and diabetes thanks to the relationship with glucose/lipid metabolism. A mechanism of increased secretion of irisin in response to reduced glucose/lipid metabolism in non-diabetic obese patients has been reported [12]. The irisin, stimulated by exercise and cold, increases the expression of the UCP-1 pump in white adipose tissue cells. White fat tissue cells which has increased UCP-1 pump in the mitochondria, is called beige fat tissue. These cells work like brown fat tissue cells. Increased UCP-1 expression inhibits ATP synthesis and leads to increased heat production which causes energy consumption in the cell, thermogenesis and glucose homeostasis are achieved $[7,13,14,15]$.

In light of this information, in this study, we aimed to determine the effects of exercise on the level of irisin hormone in experimental diabetic animal models, to evaluate the effects of metabolic syndrome components on diabetes, lipid profile, obesity and inflammation. 


\section{Methods}

In the direction of our purpose, in our study, there are 3 groups; control group, diabetic group and diabetic-exercise group. The rats used in the study were obtained from Ondokuz Mayis University Experimental Animal Application and Research Center and the steps related to animal research were carried out in this center. A diabetic rat model was developed by applying streptozotocin to rats in the study group [16]. Fasting blood glucose (FBG) levels were measured 72 hours after the administration and rats with $250 \mathrm{mg} / \mathrm{dl}$ were accepted as diabetic. While no intervention was carried out in the group in which experimental diabetic rats were placed, diabetic exercise group was applied 3 times a week, 20 $\mathrm{m} / \mathrm{min}$ walking exercise program. In serum samples taken from the tail veins of all rats in the 4th week, commercial ELISA (Rel Assay Diagnostics) kits were used to determine this parameters: irisin hormone level, FBG, serum total cholesterol, HDL and LDL levels were used to determine lipid profile, leptin level as an indicator of obesity, IL-10 and TNF- $\alpha$ is pre-inflammatory and antiinflammatory markers as an indicator of inflammation. In order to observe the obesity process, the rats in each group were weighed weekly and their body weights were measured.

\section{Results}

Morphometric measurements of the rats in the study are given in Table I.

TABLE I. MORPHOMETRIC MEASUREMENTS OF GROUPS

\begin{tabular}{|c|c|c|c|c|c|}
\hline & Unit & $\begin{array}{c}\text { Control } \\
\text { Mean } \pm \text { SD }\end{array}$ & $\begin{array}{c}\text { Diabetes } \\
\text { Mean } \pm \text { SD }\end{array}$ & $\begin{array}{c}\text { Diabetic exercise } \\
\text { Mean } \pm \text { SD }\end{array}$ & $p$ \\
\hline Baseline weight & $\mathrm{g}$ & $289,4 \pm 11,9$ & $297,8 \pm 22,2$ & $313 \pm 7,5$ & 0,208 \\
\hline Weight on the 4th week & $\mathrm{g}$ & $324,4 \pm 11,0$ & $267,8 \pm 28,7$ & $254 \pm 10,6$ & $0,001^{*}$ \\
\hline Length & $\mathrm{cm}$ & $24,3 \pm 1,2$ & $24,4 \pm 0,8$ & $24,8 \pm 1,1$ & 0,368 \\
\hline Body Mass Index & $\mathrm{g} / \mathrm{cm}^{2}$ & $0,55 \pm 0,5$ & $0,45 \pm 0,4$ & $0,41 \pm 0,3$ & 0,368 \\
\hline
\end{tabular}

$* p<0,005$

When the weights of the beginning and 4 weeks of the rats examined during the study were evaluated, an average of $35 \mathrm{~g}$ ( $\mathrm{p}<0.05$ ) increase was observed in the control group, also $30 \mathrm{~g}$ ( $\mathrm{p}<0.05$ ) decrease in the diabetic group and $59 \mathrm{~g}(\mathrm{p}>0.05)$ in the diabetic exercise group decrease was observed. It has been determined that FBG value of rats administered streptozotocin is over $250 \mathrm{mg} / \mathrm{dL}$. The mean values of the evaluated parameters are summarized in Table II. 
TABLE II. AVERAGE VALUES OF PARAMETERS FROM GROUPS

\begin{tabular}{|l|l|l|l|l|c|}
\hline & Unit & \multicolumn{1}{|c|}{$\begin{array}{c}\text { Control } \\
\text { Mean } \pm \text { SD }\end{array}$} & \multicolumn{1}{|c|}{$\begin{array}{c}\text { Diabetes } \\
\text { Mean } \pm \text { SD }\end{array}$} & $\begin{array}{c}\text { Diabetic exercise } \\
\text { Mean } \pm \text { SD }\end{array}$ & $p$ \\
\hline $\begin{array}{l}\text { Fasting Blood } \\
\text { Glucose }\end{array}$ & $\mathrm{mg} / \mathrm{dl}$ & $98,06 \pm 22,15$ & $477,17 \pm 87,98$ & $485,00 \pm 86,03$ & 0,369 \\
\hline $\begin{array}{l}\text { Total } \\
\text { Cholesterol }\end{array}$ & $\mathrm{mg} / \mathrm{dl}$ & $13,74 \pm 2,91$ & $15,29 \pm 1,44$ & $15,5 \pm 3,92$ & 0,554 \\
\hline HDL & $\mathrm{mg} / \mathrm{dl}$ & $21,69 \pm 0,73$ & $18,87 \pm 3,28$ & $20,3 \pm 0,25$ & $0,016^{*}$ \\
\hline LDL & $\mathrm{mg} / \mathrm{dl}$ & $21,69 \pm 0,73$ & $34,33 \pm 1,47$ & $28,77 \pm 4,29$ & $0,000^{*}$ \\
\hline IL-10 & $\mathrm{pg} / \mathrm{ml}$ & $2086,06 \pm 400,22$ & $2046,15 \pm 135,87$ & $1812,04 \pm 260,69$ & 0,503 \\
\hline TNF- $\alpha$ & $\mathrm{ng} / \mathrm{L}$ & $1308,58 \pm 177,11$ & $1415,75 \pm 110,61$ & $1371,67 \pm 84,81$ & 0,618 \\
\hline Leptin & $\mathrm{ng} / \mathrm{L}$ & $2069,34 \pm 121,61$ & $1911,11 \pm 441,63$ & $2008,88 \pm 263,09$ & 0,774 \\
\hline Irisin & $\mathrm{ng} / \mathrm{ml}$ & $107,73 \pm 49,79$ & $98,09 \pm 51,25$ & $66,43 \pm 25,01$ & 0,458 \\
\hline
\end{tabular}

${ }^{*} p<0,005$

As shown in Table II, the mean FBG value of the diabetic group is $477,17 \pm 87,98 \mathrm{mg} / \mathrm{dl}$ and the diabetic exercise group is $485 \pm 86,03 \mathrm{mg} / \mathrm{dl}$. When the lipid profiles were evaluated, HDL level was significantly different between the groups $(\mathrm{p}<0.05)$. The HDL level in the diabetic group was lower than in the control group, but it was determined that increased in the HDL level after exercise. Also, there was a statistically significant difference between the groups in terms of LDL levels ( $p<0.05)$. It has been found that IL-10 levels which is an inflammatory markers are reduced in diabetic groups because of the fact that diabetes suppresses immunity. TNF- $\alpha$ levels were higher in the diabetic groups than in the control group. When the irisin levels were examined, it was found that there was a difference between the groups ( $p>0.05$ ). It was determined that the level of irisin in the control group was higher than in diabetic groups. The mean irisin level of the control group was $255.73 \pm 374.81 \mathrm{ng} / \mathrm{ml}$, the diabetic group was $98.09 \pm 51.25 \mathrm{ng} / \mathrm{ml}$ and the diabetic exercise group was $66.43 \pm 25.01 \mathrm{ng} / \mathrm{ml}$. The diabetic group has a lower irisin level than the control group, similar to other studies in the literature. Leptin levels were also found that decreased in the diabetic group. In diabetic rats, it was observed that there was a negative correlation between the level of irisin and FBG ( $p>0.05)$. It was also determined that there is a strong correlation between leptin and irisin in the negative direction ( $p>0.05)$. When the relationship between lipid profile and the level of irisin was examined, it was found to be positive correlation with total cholesterol and HDL levels and negative correlation with LDL. 


\section{Discussion}

There are a number of studies that have been conducted from the knowledge of increased release of irisin resulting from exercise. Rats with hypothyroid and hyperthyroid were treated with swimming exercise 5 times a week for 1 hour, it was observed that increase in irisin level, decrease in total cholesterol, triglyceride, LDL and HDL levels. [17]. In a study investigating the effects of resistance training on the expression of the irisin in experimental animals and humans, tail-weighted stair climbing exercise was built to the rats 3 days per week during 12 weeks. Also, elastic band exercise program was applied to individuals over 65 years of age 2 days weekly consisting of 1-hour sessions and totally 12hour. It has been shown in rats that the level of irisin in the serum and muscle tissue is increased and there is an increase in muscle strength, even though there is no change in body composition. Similar results have been observed in humans and it has been found that the level of irisin in circulation rises with exercise, body composition doesn't change and muscle strength increases. These results suggest that resistance training may increase the irisin level and improve muscle function loss that may be seen in later ages [18]. When the effect of 15-20 min walking exercise 5 days a week on the level of irisin was investigated in diabetic rats, serum irisin level was found to be higher in the exercise group than in the control group [19]. It was determined that progression of obesity after 8 weeks of swimming intervention in obese rats induced by high fat diet could be alleviated. Decreases in LDL and total cholesterol levels were observed when increased levels of irisin and HDL were detected [20]. As a result of the study to evaluate the relationship between swimming exercise and serum obesity parameters, it was determined that body fat mass decreased in rats fed a high fat diet after swimming exercise. This condition is thought to result from increased levels of irisin as a result of swimming exercise [21].

\section{Conclusion}

It has been reported that the irisin is synthesized from many tissues, mainly muscle and fat tissue, as a result of exercise. Irisin is the key hormone that causes UCP-1 release in the lipid tissue, thus causing irreversible thermogenesis and weight loss, and is involved in the regulation of Body Mass Index. As a result of our study, we found that the level of irisin in diabetic rats was lower than in the control group. It was also found that there was a negative correlation between FBG and irisin. These results are similar to those in the literature. Thanks to the knowledge that the structure of the irisin hormone is $100 \%$ similar in rats and humans, researches on experimental animals are a guide for human studies.

\section{Recommendations}

Since the irisin hormone is an important alternative in the treatment of obesity and diabetes as well as other metabolic diseases, injectable irisin forms are produced; it can be considered that it can be used for controlling diabetes and obesity which are increasing day by day. In the light of current information, studies on the relation of irisin hormone with metabolic effects and diseases should be increased and the effects on the treatment of diseases should be emphasized by following developments. 


\section{References}

[1] Bulucu Altunkaynak, BZ., Özbek, E., Yağ Dokusu Endokrin Bir Organ mıdır, Dicle Tıp Dergisi, 32 (2005), 4, pp.211-217.

[2] Coelho, M., Oliveira, T., Fernandes, R., Biochemistry of adipose tissue: an endocrine organ, Arch Med Sci, 9 (2013), 2, pp. 191-200.

[3] Pahlavani, M., Razafimanjato, F., Ramalingam, L., Kalupahana, Ns., Moussa, H., Scoggin, S., et al, Eicosapentaenoic acid regulates brown adipose tissue metabolism in high-fat-fed mice and in clonal brown adipocytes, J Nutr Biochem, 39 (2017), pp. 101-109.

[4] Berköz, M., Yalın, S., Yağ Dokusunun Immünolojik ve Inflamatuar Fonksiyonları, Mersin Unıv Saglık Bilim Derg, 1 (2008), 1, pp. 1-9.

[5] Aslıhan, İ., AYPAK, SÜ., İrisin ve Metabolik Etkileri, Turkiye Klinikleri Journal of Endocrinology, 11 (2016),1, pp.15-21.

[6] Bostrom, P., Wu, J., Jedrychowski, MP., Korde, A., Ye, L., Lo, JC., et al, A PGC1-alpha-dependent myokine that drives brown-fat-like development of white fat and thermogenesis, Nature, 481 (2012), 7382, pp. 463-468.

[7] Villarroya, F., Irisin, turning up the heat, Cell Metab, 15 (2012), 3, pp. 277-278.

[8] Aydin, S., Three new players in energy regulation: preptin, adropin and irisin, Peptides, 56 (2014), pp. 94-110.

[9] Kelly, DP., Medicine. Irisin, light my fire, Science, 336 (2012), 6077, pp. 42-43.

[10] Schumacher, MA., Chinnam, N., Ohashi, T., Shah, RS., Erickson, HP.,The structure of irisin reveals a novel intersubunit beta-sheet fibronectin type III (FNIII) dimer: implications for receptor activation, J Biol Chem, 288 (2013), 47, pp. 33738-44.

[11] Novelle, MG., Contreras, C., Romero-Pico, A., Lopez, M., Dieguez, C., Irisin, two years later, Int J Endocrinol, 2013 (2013), 746281, pp. 1-8.

[12] Fukushima, Y., Kurose, S., Shinno, H., Cao Thi Thu, H., Tamanoi, A., Tsutsumi, H., et al, Relationships between serum irisin levels and metabolic parameters in Japanese patients with obesity, Obes Sci Pract, 2 (2016), 2, pp. 203-209.

[13] Zugel, M., Qiu, S., Laszlo, R., Bosnyak, E., Weigt, C., Muller, D., et al, The role of sex, adiposity, and gonadectomy in the regulation of irisin secretion, Endocrine, 54 (2016), 1, pp. 101-10.

[14] Zhang, Y., Li, R., Meng, Y., Li, S., Donelan, W., Zhao, Y., et al, Irisin stimulates browning of white adipocytes through mitogen-activated protein kinase p38 MAP kinase and ERK MAP kinase signaling, Diabetes, 63 (2014), 2, pp. 514-25. 
[15] Castillo-Quan, JI., From white to brown fat through the PGC-1alpha-dependent myokine irisin: implications for diabetes and obesity, Dis Model Mech, 5 (2012) ,3, pp. 293-295.

[16] Balgetir, F., Kocaman, N., Deneysel Diyabetik Ratların Beyin Dokusunda İrisin İmmünreaktivitesi Üzerine Losartanın Etkileri, Firat Tip Derg/Firat Med J, 21 (2016), 2, pp. 63-66.

[17] Samy, DM., Ismail, CA., Nassra, RA., Circulating Irisin Concentrations in Rat Models of Thyroid Dysfunction - Effect of Exercise, Metabolism Clinical and Experimental, 64 (2015), pp. 804-813.

[18] Kim, HJ., So, B., Choi, M., Kang, D., Song, W., Resistance exercise training increases the expression of irisin concomitant with improvement of muscle function in aging mice and humans, Exp Gerontol, 70 (2015), pp.11-17.

[19] Khalafi, M., Shabkhiz, F., Alamdari, KA., Bakhtiyari, A., Irisin Response to Two Types of Exercise Training in Type 2 Diabetic Male Rats, Arak Medical University Journal (AMUJ), 19 (2016), 111, pp. 37-45.

[20] Yang, XQ., Yuan, H., Li, J., Fan, JJ., Jia, SH., Kou, XJ., et al., Swimming intervention mitigates HFD-induced obesity of rats through PGC-1alpha-irisin pathway, Eur Rev Med Pharmacol Sci, 20 (2016), 10, pp. 2123-30.

[21] Lu, Y., Li, H., Shen, SW., Shen, ZH., Xu, M., Yang, CJ., et al., Swimming exercise increases serum irisin level and reduces body fat mass in high-fat-diet fed Wistar rats, Lipids Health Dis, 15 (2016), pp. 93. 